Marie Jelínková

\title{
A Refugee Crisis Without Refugees: Policy and media discourse on refugees in the Czech Republic and its implications
}

\begin{abstract}
Along with other Central and Eastern European counties, Czechia has invested significant effort in deterring refugees from entering the country during the 'refugee crisis'. This article sheds light on the role of the media in legitimising anti-refugee policies by analysing the politicised discourse on refugees in 900 articles published in Czech newspapers between 2014 and 2016. The findings indicate that refugees were depicted as a security threat and an administrative burden partly imposed by the European Union. The article discusses the policy implications of depicting refugees in this way and thus broadens the literature on European narratives during the refugee emergency in Europe.
\end{abstract}

KEYWORDS: 'refugee crisis', Czechia, social construction, media analysis, politicisation

RECEIVED 18 November 2018; ACCEPTED 12 March 2019.

\section{INTRODUCTION}

Studies looking at policy-making have suggested that the way in which recipients of these policies are framed influences policy decisions (Yoo, 2008). Devereux (2015, s. p.267) pointed out that the mainstream media not only sets agendas and determines what the public see as important but also shapes our understanding of the social world, the attitudes of the general public and the perspectives of those in political power. The press has the power to reflect and shape public opinion on migration issues, and there may be clear links between the media discourse and the discourse of political parties and other ideologies (King \& Wood, 2013). Media content plays a role in setting the political agenda and affects policymakers (Walgrave, Soroka \& Nuytemans, 2008). Evidence has confirmed that the media may not only promote dehumanisation of immigrants and refugees through depictions that highlight potential threats to the host society but provide ready justifications for the dehumanisation and consequent outcomes (Esses, Medianu \& Lawson, 2013, s. 531).

In relation to recent refugee emergencies in Europe, scholars have paid most attention to countries that received significant numbers of refugees. However, a few exceptions aside (e.g. Krzyżanowski, 2017), not much is known about media coverage of refugee issues and its policy implications in the CEE countries, which have remained reluctant to accept refugees despite the fact that some of their neighbouring counties (e.g. Germany) have accepted many. In 2017, Czechia, Poland and Hungary were all referred to the EU Court of Justice for non-compliance with their legal obligations on relocation. Despite the possible serious consequences of this, these countries' governments received vast public support for their stance on this issue.

In Czechia, the numbers of refugees crossing the border or applying for asylum have been extremely low but the 'refugee crisis' was nevertheless immensely present in public debates and media coverage on the issue was to a certain extent self-constructed (cf. Triandafyllidou, 2017). Migration and the perceived 'refugee crisis' began to attract media and political attention in the second half of 2014, and the debate focused on security issues from the outset. Although there was no substantial increase in the number of asylum seekers in the country and the percentage of Muslims in the country is less than $0.1 \%$ (Czech Statistical Office, 2017), the perceived threat of Islam played a major role in both political and media discourse. The aim of this article is to analyse the main framework of the Czech media coverage of refugee issues in response to the 'refugee crisis' and thus broaden the debate on how the politicisation of refugee issues is legitimised. Moreover, I seek to understand what the implications of this media and political construction of refugees are. Through qualitative thematic analysis, I identify the themes and patterns connected with coverage of refugee issues. I then use 
quantitative analysis to capture the main characteristics of newspaper articles. The analysed period (2014-2016) coincides with the growing, peaking and slowly diminishing 'refugee crisis' in Europe.

The article proceeds as follows. The next section briefly introduces the theory of the social construction of the target populations, providing some background to the matters I discuss further on. After this, I describe the Czech asylum policies, stressing key events in the Czech position towards refugees during the analysed period (2014-2016). This is followed by a presentation of the methodology and results of my analysis of printed media articles on refugees. The article concludes with several reflections on the current political implication of the results.

\section{THEORETICAL FRAMEWORK: THE SOCIAL CONSTRUCTION OF TARGET POPULATIONS}

The media play a large role in framing public policy and discourse about migrants, constructing and promoting particular positions on these issues (Esses et al., 2013). Many studies have documented that negative media portrayals of both immigrants and refugees tend to promote the dehumanisation of these groups (ibid.). Moreover, Perloff (2010) illustrated that citizens are susceptible to being persuaded by the views expressed by their leaders and by the media and that politicians manipulate the topics by promoting one way of looking at a problem rather than another (ibid.). The politicisation of migration is often connected with growing securitisation, which portrays immigrants as a challenge to the protection of national identity and welfare provisions (Huysmans, 2000). Schneider and Sidney (2009, s. 105) claimed that justifications and legitimisations for policy are intertwined with policy design towards immigrants. The characteristics of the policy design emerge from a social and political process, and these characteristics in turn feed into subsequent political processes (ibid.). Thus, to analyse and interpret policy design towards refugees and its consequences in Czechia, I draw on Schneider and Ingram's $(1993,1997)$ theory of the social construction of target populations and use it as a theoretical framework to examine media coverage as indicative of public opinion and policy responses towards immigrants and refugees (cf. Lawlor \& Tolley, 2017).

Primarily, the theory focuses on the target population's position in public policies and explains why some groups are more advantaged than others or how policy design reinforces or alters their advantages. The theory contends that social constructions of target populations influence the policy agenda and the selection of policy tools, rules and rationales for delivering benefits and burdens, as well as the rationales that legitimate policy choices (Schneider \& Ingram, 1993, s. 334). Social constructions become embedded in policy as messages that are absorbed by citizens and affect their orientations and participation patterns (ibid.). Moreover, as Schneider and Sydney put it (2009, p.111), these messages are interpreted and internalised by target groups and other players in the policy arena, shaping the way citizens view the problem and shaping their perceptions of whether the interests of target groups are a legitimate public concern. The authors (1997:113) conceptualised the target group constructions in terms of (a) the negative or positive message they convey and (b) the power (resources) available to target groups to challenge or reinforce that message. The convergence of power and social construction creates four types of target populations: (1) advantaged groups that are perceived to be both powerful and positively constructed (e.g. business); (2)contenders (e.g. the rich), who are powerful but negatively constructed, usually as undeserving; (3) dependants (e.g. children, seniors), who are considered politically weak but carry generally positive constructions; (4) deviants (e.g. criminals), who are weak and negatively constructed as undeserving and of no value to society. The theory explains how social construction and power shape policy designs, which in turn affect citizens' perceptions and political participation. Burdens are oversubscribed and benefits undersubscribed (relative to the optimal balance for solving the given problem) for the undeserving groups; the reverse is true for the deserving groups. The way policies are set up relative to their recipients and the message that governments send to the target population and to voters more generally have the effect of either strengthening or weakening their behaviour and (self)perception (a feed-forward effect). The relationship between policy design and the target populations is thus not (causally) linear but is mutually constitutive and cyclical. As Schneider (2013, s. 222) puts it, 'political dynamics produce policy designs and these, in turn, "feed forward" to produce not only policy results but also to influence the subsequent "politics" of the society'. Moreover, the designs tend to reproduce the same kinds of politics as those from which they emerged (Schneider and Ingram, 1993; 2005). In their recent work, Ingram, Schneider and deLeon (2015, p.124) elaborated the theory further with respect to values and emotions. They pointed out that current social-psychological research reinforces social constructions whilst shedding light on the 
fact that humans decide first by hasty heuristics and only later engage rational thought in justification. This part of the theory explains human tendencies to construct the 'other' in value-laden, emotional and symbolic terms.

As mentioned above, the social construction of target populations intertwines with policy design towards these groups. In the section that follows, the development of Czech refugee policy design is briefly outlined.

\section{POLICY DESIGN TOWARDS REFUGEES IN THE CZECH REPUBLIC: DEVELOPMENT, EVENTS AND PUBLIC OPINION}

The Czech Republic's present reluctance to accept refugees contradicts Czech historical experience: numerous people from former Czechoslovakia fled as asylum seekers to Western Europe in the 1960s, 1970s and 1980s. In 1991, as soon as it could, after the fall of the communist regime, Czechoslovakia joined the 1951 United Nations Convention Relating to the Status of Refugees and became a refugee-receiving country (Szczepanikova, 2005). Nevertheless, the number of asylum applications the country received has consistently paled in comparison to many Western European countries and has dropped even further after Czechia joined the Schengen area in 2007. Since then there have been between 700 and 2,000 asylum applications per year, with only a limited increase in 2015 and 2016. Between 1993 and 2016, the total numbers of successful asylum applications in Czechia only reached 3,129 positive asylum decisions and 2,153 positive decisions on subsidiary protection (of 91,700 asylum applications). Hence, the numbers of asylum applications and individuals granted asylum were low even from a long-term perspective (this situation is similar in most of the CEE countries). This cannot be understood to be purely a result of the country's geographical position and the application of Dublin regulations. Drbohlav and Valenta (2014) presumed that since Czechia has never accepted a significant number of refugees (with the exception of 6,000 Yugoslavians between 1991 and 1997), almost no ethnic communities that would attract further asylum seekers of the same origins exist. Nevertheless, the reasons for such low numbers of asylum seekers are also connected with administrative and other barriers: longer asylum procedures and a high rejection rate in comparison to west European states; a ban on asylum applicants working during the first year; the fact that the courts often overturn decisions taken by the Ministry of Interior, and the process starts all over again; all this implies a long-term, but unspoken (political), reluctance to accept refugees (Rozumek, 2017). This position can also be seen in various recent unsuccessful attempts at promoting relocation schemes.

Similar to Poland and Slovakia, Czechia resettled a number of Christian refugees (somewhat unsuccessfully) because they were supported by a private sponsor. After an intensive political lobby led by the endowment fund Generation 21 (Gen 21), the Czech government approved the relocation of 153 refugees from Iraq in December 2015 on condition that Gen 21 would cover most of the related expenses. The government's approval for this project came as a surprise, because the Czech law does not mention the possibility of private asylum sponsors. The Iraqi Christian refugees faced a variety of difficulties after arriving in Czechia (often concerning mismatched expectations); some of them left for neighbouring Germany, whilst others later returned to Iraq. The project was quickly suspended by the government. Only 35 Iraqis (of 89 who had come) stayed. The tremendous efforts by many Czech citizens, both Christian and non-Christian, to welcome them and assist with their integration fell rather flat. The project was widely adopted by politicians, the media and the general public as an example to support the argument that refugees do not want to settle in Czechia.

Although there was no substantial increase in the number of asylum seekers in the country, the number of non-citizens crossing Czech territory using the Western Balkan route to reach Germany and other countries increased significantly from 2014 onwards. In response to this, the country boosted its detention efforts. The refugees tended not to apply for international protection and, when apprehended by the police, were detained under the Act on the Residency of Foreigners. In 2015, 3,121 non-citizens were detained, and in 2016, that number almost doubled. Most of the detainees came from Syria, Afghanistan and Iraq. Nonetheless, the detainees' situation was disputable. Czechia has received sharp criticism from the UN High Commissioner for Human Rights for its inadequate detention conditions, for obliging immigration detainees to pay for their confinement and for detaining (accompanied) minors. The Commissioner stated that 'the violations of the human rights of migrants are neither isolated nor coincidental, but systematic: they appear to be an integral part of a policy by the Czech Government designed to deter migrants and refugees from entering the country or staying there' (UNHCR, 2015). Refugees heading to Germany were detained under the Dublin regulation to be (mostly 
unsuccessfully) returned primarily to Hungary. The majority of detainees were subsequently released after 40-90 days and headed west. Detention centres were overcrowded, and the detainees (who were obliged by law to pay for their stay and meals) could not satisfy their basic needs. Lawyers seeking to access the detention centres to provide services also faced profound obstacles. The Public Defender of Rights undertook several investigations in a detention centre and, as a result, claimed that 'the children in the facility have worse living conditions than inmates in Czech prisons' (Public Defender of Rights, 2015).

The issue of migration and the refugee crisis started to attract more attention from the media (and politicians) in the second half of 2014 and was framed as a security issue from the outset. Czech president Zeman repeatedly expressed his negative attitude towards refugees and Islam. Prime Minister Sobotka (Social Democrats) took a more liberal position but respected the restrictive approach towards the refugee issue articulated by all the political parties in parliament. Although Czechia vehemently opposed the idea of compulsory relocation quotas, it committed itself to receiving almost the same number of refugees as the Commission had proposed in the very early stages of discussions. Several legislative measures against refugees, immigration and, as some of the politicians in media claimed, 'the Brussels dictatorship' (a phrase which for Czechs echoes the former "Moscow dictatorship") were proposed, which in general violated international obligations. All of them were unanimously disapproved by the government. Nevertheless, the state's position towards transiting non-citizens and the situation in detention centres shows the very negative policy message towards potential asylum seekers.

Unsurprisingly, this negative political message towards refugees, and the fast-growing Islamophobic movement, which linked refugees and Islam together, gained significant media attention and received significant public support. Notwithstanding that, the non-governmental organizations, the religious community and other civil society actors responded to the refugees' humanitarian needs. Hundreds of Czech volunteers travelled to the Balkans to assist refugees, and support was also evident for those in detention.

Before the refugee crisis, Czech society had been stable in its opinion on immigration between 2008 and 2013: almost half of the population believed that there were too many foreigners living in the country, around $40 \%$ found the number of foreigners appropriate and $2 \%$ wished to have more foreigners in the country $(\boldsymbol{C V} \boldsymbol{V} \boldsymbol{M}, \mathbf{2 0 1 3})$. However, the same survey also showed that $77 \%$ of the population was willing to accept people fleeing from war, famine or natural disaster in their country. Between 2013 and 2015, public opinion towards accepting refugees changed significantly. According to a survey from December 2015 , only $2 \%$ of Czechs were willing to accept refugees, $60 \%$ were against any acceptance of refugees and 33\% were willing to accept refugees only temporarily, until the situation enabled them to return to their country of origin; the vast majority of respondents perceived refugees as a security threat (CVVM, 2015). Apparently, this prevailing negative opinion of refugees was linked to the refugees' particular countries of origin: $43 \%$ of Czechs were willing to accept people fleeing Ukraine (despite the fact that some of these respondents expressed a general unwillingness to accept refugees) but 79\% were against accepting refugees from the Near East and northern Africa ( $C V V M, 2015)$. The same survey conducted 1 year later $(C V V M, 2016)$ revealed that the position of the Czech society remained practically the same, although the topic was receiving slightly less attention in the public sphere by this stage.

\section{HYPOTHESES}

Schneider and Ingram (1997) pointed out that policymakers choose from amongst a variety of possible approaches to addressing a particular problem. In their further work, Schneider and Sidney (2009, p. 111) called for more systematic analysis of the effects of public policy designs on the most critical issues of our time, including the framing of issues in such a way that policymakers would rather 'win' and defeat the 'enemies' than they would solve a collective problem. The case of media portrait of the migration crisis in the Czech Republic presents such issue. Tkaczyk (2017, p. 96) illustrated that the media coverage of the (European) migration crisis in the CR was framed through the security perspective also because of the advanced instrumentalisation of the issue by the Czech political actors. Nevertheless, he did not elaborate the role of politicians in covering the migration crisis in this respect more. Hence, this study also aims to examine the role of Czech politicians (or more accurately their quotes) in media discourse more deeply. The role of politicians in the discourse on immigrants has been discussed by Esses et al. (2013, p. 519), who pointed out that media and political elites take advantage of uncertainty of public about the migration issues (such as cost and benefits of migration, numbers of asylum seekers, the extent of threats to members of host society). Little direct information enables portraying migrants from a security perspective. In the following study, Esses et al. (2017, p. 85) developed their findings and concluded that politicians often leverage 
the consequences of perceived thread and competition from refugees and thus tend to discuss migration - almost purely - from the security perspective. On the basis of these findings, the first hypothesis in this article seeks to answer whether or not the Czech politicians talk about refugees from a security perspective in media.

Furthermore, several studies confirm (e.g. Kirkwood, 2017) that the 'moral duty' or obligation to help refugees is related to believe that the refugees deserve protection (their claim to seek protection is legitimate) or not. Following this, Esses et al. (2013) noted that the dehumanisation of refugees is often caused also by omitting the push factors of (forced) migration. For that reason, the second hypothesis investigates whether the Czech politicians talk about the causes of migration in media or not. The last hypothesis (about the negative stance towards the European Union by the Czech politicians) stems from the findings of the thematic analysis (see below) and from the observation that the narrative of a migration crisis became linked to rising Euro-scepticism in various countries (Scholten \& van Nispen, 2015). It also partly reflects Triandafyllidou's (2017, p. 10) findings on how political discourses on refugees crisis are rationalised. Triandafyllidou (ibid.) noted that media and political debates (re-)produced in media were also contextualised into current challenges including Euro-scepticism.

\section{METHODOLOGY}

The media analysis that I present follows a mixed methods approach and incorporates both quantitative content analysis and qualitative thematic analysis of newspapers for a 3-year period (cf. Sulaiman-Hill, Thompson, Afsar \& Hodliffe, 2011). The analysed timeline is between 1 January 2014 and 31 December 2016, as my preliminary research revealed that newspapers hardly wrote about refugee issues until mid-2014 and so this timeline enables me to trace the changing patterns of 'refugee crisis' coverage. In this study, the qualitative and quantitative approaches are seen as complementary to answer the research questions. The qualitative thematic analysis is used to identify the themes and patterns connected with refugees and to analyse the tone of the articles and their position towards refugees (Braun \& Clarke, 2006). This part enables me to gain a more in-depth view of the articles. On the other hand, the qualitative content analysis techniques enable us to indicate the general characteristics of articles on refugees, test several hypotheses and grasp the main changes over time (Riff, Lacy \& Fico, 2014).

The three most read daily newspapers in Czechia were analysed: Blesk (daily tabloid newspaper, politically neutral); MF Dnes (right-wing conservative) and Právo (left-wing). A broad search of the Newton media database for the keyword 'refugee/refugees' during the period in question provided 6,092 articles from these papers. Of these, 5,609 related to the refugee agenda (Blesk: 648, MF Dnes 2550, Právo: 2495). Systematic random sampling was used to obtain a representative sample for further analysis: every seventh article from MF Dnes and Právo and every third from Blesk (sorted by the issue date, hence the sampling also reflects the development over time). In total, 900 articles were retained for content and thematic analysis (Blesk: 187, MF Dnes 357 and Právo 356). The keyword used for searching was 'refugee/refugees', and only articles including this term were used in the sample.

All the coding was done by one person (the author) and checked by another person. The codes were consequently analysed, mapped and sorted into potential themes. The set of candidate themes was reviewed and redefined through further coding and mapping, following the procedure of thematic analysis (Braun \& Clarke, 2006). All articles were then coded for the presence of at least one (but possibly more) theme. Around $2.5 \%$ of articles did not contain any of the 11 key themes; these were, for example, articles about holidays or history.

The results of the quantitative analysis report the main characteristics of the articles from the perspective of time distribution, the tone adopted towards refugees, references to terrorism and Islam and quoted actors. The theoretical framework (see above) suggested that politicians played an import role in promoting both anti-refugee and anti-EU rhetoric. Hence, the following hypotheses about the role of Czech politicians (or more accurately their quotes) in media discourse were tested as a part of my subsequent quantitative analysis:

H1: Czech politicians talk about refugees from a security perspective in media.

$\mathrm{H} 2$ : Czech politicians do not talk about the causes of migration in media.

H3: Articles that feature the views of Czech politicians take a negative stance towards the European Union.

Hypotheses were tested using Pearson's chi-squared. The level of significance was set at 0.05 ( $\alpha=0.05)$. 
The slant of each article was assessed holistically: no extra attention was paid to the headlines or the first paragraph. All 900 articles in the sample were numbered, the coded data were analysed in $\mathrm{R}$, the frequency and distributions of data were calculated and the main themes were tabulated by newspaper and period.

\section{RESULTS}

\section{QUANTITATIVE ANALYSIS}

Refugee-related topics started attracting attention in the second half of 2014 and gained importance in summer 2015 when the number of refugees arriving in Europe increased significantly and provoked intense media debate. The number of articles peaked in September 2015 when both the Eastern Mediterranean and the Western Balkan routes were being used by unprecedented large numbers of people coming from or via Turkey. A smaller media splurge in the press occurred in February 2016 over the Iraqi Christian refugees. Notwithstanding that, since the second half of 2016, the debate on immigration has tended to be limited to news, and although it is mentioned on an almost daily basis, this is largely marginally in comments and opinions. The distribution of articles on refugees followed the same pattern in all three analysed newspapers.

Graph 1: Time distribution of articles

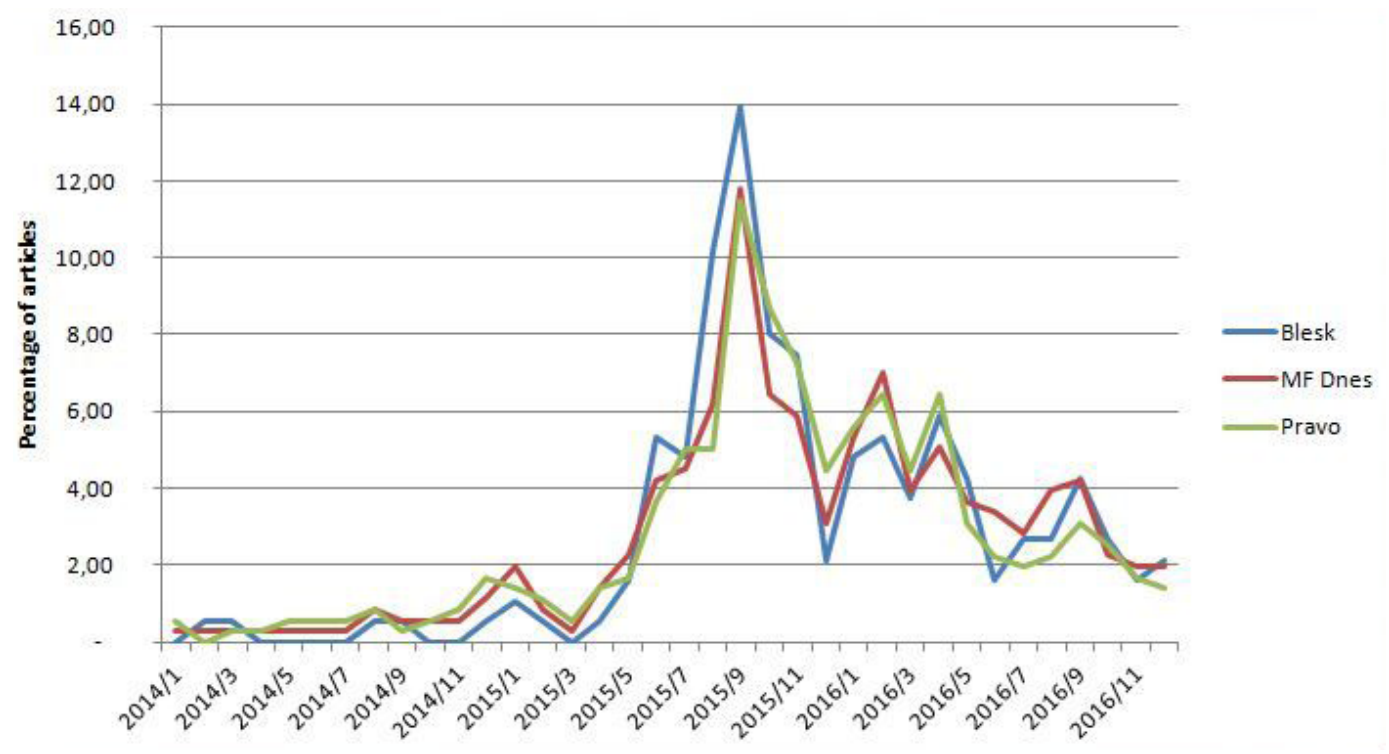

The $18 \%$ of the analysed articles were negative in overall tone, $32 \%$ positive, $43 \%$ neutral and $7 \%$ ambiguous. Nevertheless, if we look at how they describe refugees, we see that the articles were not so neutral but rather negative or ambiguous in relation to refugees and events connected with them: when we take into account the articles' tone in relation specifically to refugees, the result is a drop (especially in the second and third year studied) in the number of neutral articles (from 43\% to 33\%) and a growth in negative tone (from $32 \%$ to $37 \%$ ) and ambiguous comments (from $8 \%$ to $11 \%$ ), whilst the percentage of positive articles remained practically unchanged (19\% specifically positive about refugees; $18 \%$ positive overall).

Connections between refugees and Islam were hardly made at all in 2014, but this changed in 2015 when $16 \%$ of articles were affected, and in the following year, $11 \%$ were affected. Most of these articles also mentioned terrorism. As with the connections to 
Islam, a link between refugees and terrorism was only drawn in 2015 ( $9 \%$ of articles), but this did not drop the following year (2016) but instead rose to $14 \%$.

The $60 \%$ of the articles featured people's views. These were representatives of Czech political parties in one-third of cases and the Czech President in a further 7\%. It is interesting that refugees themselves were cited less frequently in the Czech press (6,5\%) than the President. In the discussion of my hypotheses below, I evaluate the President's comments as well as those made by other Czech politicians in Czech media.

Hypothesis (H1): 'Czech politicians talk about refugees from a security perspective in media' was generally confirmed ( $\chi$-squared $=4.3046 ; \mathrm{df}=1 ; \mathrm{p}$-value $=0.03801$ ). If we then look at the differences between the political parties in this, representatives of the then governing party ANO $2011^{1}$ talked about refugees in relation to security most often $(\chi-\mathrm{squared}=$ 8.3807; $d f=1 ; p$-value $=0.003792)$. The Social Democrats (who were in the governing coalition together with The Christian and Democratic Union - Czechoslovak People's Party and ANO at the time) also frequently mentioned security in relation to refugees but this was not statistically significant $(\chi$-squared $=2.2562 ; d f=1 ; p$-value $=0.1331)$, for the other parties this hypothesis is not significant, but we cannot generalise based on the very small numbers of comments involved.

Hypothesis (H2): 'Czech politicians do not talk about the causes of migration in media' was not confirmed $(\chi$-squared $=3.2027 \mathrm{e}-$ 28 ; $\mathrm{df}=1$; p-value = 1); however, this result must be interpreted bearing in mind that, overall, the number of articles that mention the causes of migration is very small. It is, therefore, reasonable to state that the articles almost always ignored the causes of the refugee crisis and no one (including the politicians) commented on them.

Similarly, hypothesis (H3) 'Articles that feature the views of Czech politicians take a negative stance towards the EU' was found to be true $(\chi$-squared $=12.842 ; \mathrm{df}=1 ; \mathrm{p}$-value $=0.0003389)$. It should be noted that within the term politicians (in media), we included numerous parties both in government and in the opposition and the country's president.

\section{QUALITATIVE THEMATIC ANALYSIS}

The qualitative thematic analysis revealed 11 main themes:

Overall, the most commonly mentioned theme was the Political and administrative burden of the 'refugee crisis'. This major theme presented refugees as a rather distinctive and political 'issue to solve' from the beginning of 2014. The robustness of this theme (on an average, $44 \%$ of articles) illustrates that the 'refugee crisis' was perceived, to a large extent, as a distinctly 'administrative' topic. Most of the articles on this theme remained neutral and very descriptive. However, the Czech newspapers gradually adopted a vocabulary that was presented as descriptive and neutral but strongly linked the refugee issues to natural catastrophe. The first sentence of an article describing developments in Turkey demonstrates this:

Europe is threatened with an influx of refugees and Turkey warns that it might be not able to cope with the next wave of runners who flood its territory. (Právo 11.7.2015)

Other news often combined very descriptive characteristics with more or less hidden advocacy of the Czech newspapers' general tone of message on refugees. In articles about other countries, this advocacy was connected to an 'awakening' (in Germany or Austria) that their positive attitude towards refugees would not last.

Vienna, which was open towards refugees early on, has changed its attitude during the past year and now supports closing the borders on the Balkan route. (MF Dnes 21.6.2016)

The Security issue theme appeared in 2015 and lasted into 2016. One-fifth of the analysed articles linked refugee issues to security. This link was much more common in the tabloid newspaper Blesk (31\%) than in Právo (15.6\%) or MF Dnes (17.6\%). The securitisation discourse often used a dichotomy between Czechia as a safe country and the dangerous anonymous mass of refugees. The refugees were pictured as a threat from the perspective of terrorism, criminality or challenging integration. The portrait of refugees as a threat to 'our' way of life was present in several stories but these almost never referred to particular stories or examples. Refugees were primarily seen as threatening the status quo. The stereotypical picture of refugees as (dangerous) dark-skinned young Muslim men with expensive smartphones who refused to fight for their country dominated the discourse. The most critical articles

1 ANO 2011 is a Czech political party run on a business model and founded by businessman and billionaire Babiš. 
Tab. 1: Themes

\begin{tabular}{llll}
\hline \multirow{2}{*}{ Theme } & BLESK & PRÁVO & MF DNES \\
\cline { 2 - 4 } & $\%$ & $\%$ & $\%$ \\
\hline Political and administrative burden & 48,1 & 53,7 & 33,9 \\
\hline Security (fear, terrorism, criminality) & 31 & 15,7 & 17,6 \\
\hline Migration as an internal issue & 13,4 & 9,6 & 28 \\
\hline Organization of migration, refugees in EU & 12,8 & 12,9 & 14,8 \\
\hline EU refugee quotas & 9,1 & 9,8 & 3,1 \\
\hline Aid to refugees & 4,8 & 7,3 & 5,6 \\
\hline Public opinion on migration issues & 3,7 & 5,1 & 7,3 \\
\hline Causes of refugee crisis & 3,2 & 6,5 & 3,4 \\
\hline Detention centres & 5,3 & 2 & 6,2 \\
\hline Iraqi Christian refugees & 5,3 & 1,7 & 2,8 \\
\hline Refugee stories & 5,3 & 0,6 & 1,7 \\
\hline
\end{tabular}

on this theme also featured news about the Czech police or army and their ability to protect the national borders, or about police migration control. The following quotation from the Czech Ministry of Interior illustrates several aspects of this theme:

We have claimed since the beginning that allowing everybody who arrives with the migration wave to enter Europe is highly problematic. It is honest to say that terrorists use the migration wave to send their fighters to Europe. That is obvious. Anyone who does not admit that is lying. However, migration cannot be absolutely connected to terrorism. (Právo 21.12.2016)

The prevailing discourse claimed that Czechia did not support the recent developments concerning the 'refugee crisis' and blamed the (distant) European Union for failing to manage the situation well. Second, it pictured Czechia as a country proposing an effective solution, and, third, it presented information that implied a balanced point of view. In media, the security discourse was often echoed by Czech politicians, especially the president. The 'illegal' status of refugees or their 'unauthorised' stay was often highlighted; this served as a tool to legitimise the more restrictive Czech approach.

The percentages of articles connected to Migration as an internal issue differed significantly across the newspapers studied (28\% in MF Dnes compared to only $9.6 \%$ in Právo); however, this was mostly a theme discussed in short news items describing, for example, action by the police, statistics or brief political news. This theme gained attention mainly in 2015 . Czechia was pictured as a country that supported aid to refugees but preferred to provide help in the refugees' countries of origin. Public safety and the absence of terrorist attacks were often connected with the fact that Czechia had a low number of migrants. Most of the articles on this theme echoed the government's emphasis on protecting its citizens and the assurance that Czechia remained a safe country.

The Czechia is giving 140 million CZK to Afghanistan over three years to help keep people in their home country. This is the way forward for all of Europe... (Právo 27.8.2015)

As the title of our third theme, Organisation of migration and refugees in the European Union, suggests, the organisation of migration was often connected with the current situation of migrants in the European Union, especially in neighbouring Germany. The key argument that most frequently underpinned the stories on this theme questioned refugees' eligibility for international protection. Refugees were said to have paid large sums to smugglers in order to migrate to wealthy European countries. The tone of this theme was set by comments that the refugees should have stayed to fight for their 'own' country for their 'own' good. An overall balanced picture of refugee integration (mainly in Germany) was often accompanied by personal stories from people who had, for example, been taken out of public housing and left homeless. The articles often focused on welfare frauds and the possible misuse of undeserved state handouts.

Refugees receive more money in benefits than the pension an Austrian farmer receives after working hard his whole life. (Právo 16.9.2016)

The minor theme of the EU refugee quotas is very closely related to the first theme and might be considered a subtheme. Nevertheless, the articles that focused on the EU refugee quotas often used more expressive argumentation, stressing that quotas 'could not work' and 'refugees are not interested in living in Czechia'. The proposed relocation scheme was related to more general 
criticism of the European Union (the 'Brussels dictatorship') and pictured as a threat to national sovereignty. The coalition of ('befriended') Visegrad countries was highlighted and used to contrast against the hostile and incompetent EU.

The Czech Republic has lost! The European Union has forced us to accept refugees. For now, we must accept 1591 asylum seekers mainly from Syria, Iraq and Eritrea. Czech resistance was in vain; Poland betrayed the Visegrad group! (Blesk, 23.9.2015)

The Aid to refugees theme could be considered marginal, as the newspapers did not pay much attention to the many Czech volunteers who travelled to the Balkans to assist refugees or to protest against their detention in Czechia. Approximately $6 \%$ of articles mentioned some form of aid to refugees, but usually only as a minor side theme. People assisting refugees were sometimes pictured as young and naive, but most articles also highlighted the positive aspects of their involvement. The refugees who received assistance were pictured as deserving of it. This contradicts the general picture of refugees in which the migrants' legitimacy was questioned and their 'illegal' status emphasised.

... thousands of refugees are waiting there in a rain for endless hours. Only several tend of mainly Czech volunteers helps them. (MF Dnes, 24.10.2015)

The longer the 'refugee crisis' lasted, the more space was given to public opinion. Articles on the theme of Public opinion on migration issues consist primarily of the results of opinion polls and opinions expressed in interviews by members of the public. Practically, none of the articles on this theme could be considered positive. Respondents usually expressed fears over the number of refugees, their gender and age (young males) and the perceived threat they posed to the 'Czech' way of life and questioned why they had left their countries of origin.

Three fifth of the nation believe, that Czechia should not accept refugees from war zones. (MF Dnes, 1.12.2015)

Only between 3\% and 7\% of articles (depending on the type of newspaper) mentioned or focused on the Causes of the refugee crisis. Czech newspapers distinguished between developments 'over there' (e.g. in Syria) and 'over here' (how the European Union dealt with the refugees); no link was usually made between these two worlds. The articles on this theme mainly described developments in Syria and stated that, as a result, thousands of people had been forced to leave their homes. Nevertheless, these war victims were usually not seen as related to those who were already present in the European Union. As the following quotation shows, the causes (if there were some) were often more about the context, the time frame or the trigger.

The West did not pay attention to Syria, when 250 thousands died but when first tens of thousands refugees arrived. (Právo, 15.12.2016)

Detention centres were mentioned most frequently in 2015 and framed from two perspectives. The prevailing one focused on the 'protection' of Czech (local) people from an 'uncontrolled' massive flow of 'illegal' (and thus 'dangerous') immigrants. The Ministry of the Interior in particular amplified the aspect of control and protection. A smaller but still significant amount of attention was paid to problematic conditions in the detention centres, although this was often 'balanced' by the opposite perspective, as illustrated below.

'The toys are completely new. (...) Obviously, everything is freshly prepared. (...).' 'The refugees destroyed everything; they refused the clothes, which were given to them in response to their humanitarian need, they put them in sacks and threw them away (...). They do not have any manners, they shit outside the toilet bowl (...) says the maintenance man.(...)'. 'We feel like we are in prison. We passed through ten states, and only here were we detained. It is like a prison', repeats Nazari, a refugee from Afghanistan (MF Dnes, 6.11.2015).

The theme of the Iraqi Christian refugees, which was mainly mentioned in 2016, was the most ambiguous one. On the one hand, these articles documented the willingness of some Czechs to welcome refugees; on the other hand, the subsequent disappointment at the scheme's limited success amplified the Ministry of the Interior's argument that 'refugees are not interested in staying in Czechia'. Nevertheless, around half of the articles reflected on or at least mentioned the tricky role of TV Prima's involvement in the scheme ${ }^{2}$ and its biased coverage of the theme.

Luxury, freedom and own apartment? Refugees, who applied for asylum in Czechia and left to Germany, can forget all of that. (Blesk, 11.4.2016)

The fact that the last theme, Refugee stories, is also the smallest (from 5.3\% in Blesk to $0.6 \%$ in Právo) and reveals that Czech newspapers almost entirely failed to present a picture of the refugees as human beings with their own stories, which strongly reinforces the overall dehumanisation of refugees in the articles (they were often referred to as a 'flood', 'swarm' or 'marauders'). The slightly

2 TV Prima offers a prime example of media bias: leaked documents from an internal meeting of company executives and editors (on 7 September 2015) showed that managers gave journalists direct instructions to portray refugees as a threat and in a negative light. Their reporters also partly misinterpreted a translated interview with the Iraqi refugees. 
higher number of refugee stories covered in Blesk is due to several brief stories attached to primarily dramatic photos of refugees. The refugee stories' articles can be clustered into three groups: (1) stories of refugees who had had difficult journeys to Europe and were living in refugee camps in Greece/Italy; (2) stories of male (usually Syrian) refugees who were happy to be in Germany but found life and/or integration there difficult and (3) interviews with well-integrated migrants in Czechia who (critically) commented on the integration of refugees.

They have decided to travel by land. They cannot swim and the last message from their friends was from a sinking boat. (MF Dnes, 6.2.2016)

\section{DISCUSSION}

One critical issue that underpinned much reporting on the refugee crisis was the idea that only a minor proportion of refugees were eligible for asylum and that their integration would be challenging. My media analysis shows that political aspects of the refugee emergency were the most reported and that refugees were referred to as anonymous objects in political discussions (sim. Tkaczyk, 2017). This prevailing 'descriptive and distant' approach was present throughout the analysed period. The refugee situation gained importance in summer 2015 when large numbers of refugees arriving in Europe were perceived to be beyond the control of the EU authorities or particular states involved. After that, the topic received less attention but still significantly more than it had in 2014. Nevertheless, the securitisation discourse has come to the fore since 2015 and the 'threat' of refuges and issue of 'EU badly managed policies towards refugees' are frequently mentioned as evidence to legitimise the Czech government's position. As Murray and Marx (2013) pointed out, such securitisation is one of the most important predictors of negative attitudes and prejudice towards immigrants.

The Czech president, along with other political leaders, played an important role in shaping public opinion on refugees (cf. Perloff, 2010). Furthermore, my study indicates that the Czech position was largely unconnected to the positioning of political parties. Practically, all political parties held anti-refugee positions and used fear of refugees to boost their political standing. All of them perceived the topic as a matter of national security and as related to a negative view of the EU policies. Their views were amplified by the stereotypical representation of undeserving, dehumanised refugees presented in the media, which was strengthened by the media's failure to cover the causes of the refugee emergency in any detail (see, e.g. Yoo, 2008 and Esses et al., 2013). Furthermore, between 7\% and 15\% of articles linked refugees to Islam, especially in 2015 and, to a slightly lesser extent, in 2016. The tone of these articles was predominantly negative, as the connection to Islam was perceived as linked with terrorism and cultural threats (cf. Esses et al., 2017). To sum up, the almost untimed use of refugee stereotypes, a lack of personal stories and a focus on challenges to refugee integration narrowed the public understanding of who the refugees were (Devereux, 2015).

\section{FINDINGS FROM THE PERSPECTIVE OF APPLIED THEORY}

From the perspective of the theory of social construction of target populations, what we have seen in this article of Czech policy design towards - and media coverage of - refugees offers almost an entirely negative picture of refugees; they might be understood as an example of the undeserved and weak group - deviants. Albeit social constructions are subject to change, such widely shared social constructions are extremely difficult to refute, even for the small number of persons who disagree with them (Schneider $\&$ Ingram, 1997). Not surprisingly, several previous analyses (e.g. Jørgensen \& Thomsen, 2012; Pierce et al., 2014) have shown that in various contexts, groups of migrants have been classed as deviants. Czechia presents a case in which negative press coverage helped shape public attitudes towards asylum seekers almost before any had arrived in the country. Deviants are usually proximate punishment policy targets, and the extent of the burdens placed on them will be greater than is needed to achieve effective results (i.e. oversubscribed). The Czech use of detention centres for refugees, which the European Court of Justice recently found unlawful (ECLI:EU:C:2017:213), confirms this aspect of the theory. This policy of detaining transiting refugees served to promote the perception of refugees as a threat and to justify their inhumane treatment (cf. Esses et al., 2017), which was often advocated in the media. Similarly, the theory states that some public officials engage in private politics or outright deception and the dominant tools are expected to be more coercive and often involve sanction, force or even death. Such promise correlates with many statements 
in the analysed press, for example, when the media advocated coercive police action as a necessary approach to promote security. The theory also posits (Schneider \& Ingram, 1993) that benefits conferred on deviants are frequently claimed to be unavoidable to protect important constitutional principles that confer rights on everyone. This was especially visible in the media's prevailing attitude, which echoed Czech political discourse and stressed security and protection of 'our' culture and values. The authors (ibid.) noted that powerless groups are viewed as needing direction 'for their own good'. Such directions might be, for example, seen in the media arguments against accepting refugees on the grounds that 'it would enable them to escape instead of taking action in their own country'. This argument reveals that the media commonly failed to picture refugees as war victims. Furthermore, the construction of the target group influences how the groups are viewed; for example, when opposed to powerful segments of society, 'the deviants' are viewed as undeserving people whose behaviour constitutes problem for others, whilst they see themselves as lonely players who have no chance of winning in a game (Schneider, Ingram 1993). This part of the theory brings another policy implication: if they receive any benefits, the society considers those to be an unjustified favour and that social perception influences their identity. These social perceptions might constitute a significant barrier to refugee integration in Czechia (cf. Esses, Jackson \& Armstrong, 1998).

\section{CONCLUSIONS}

To conclude, public policies and reactions to them are not innate but rather socially constructed (Lovell, 2003). The 'deviant' construction of refugees was used as grounds to legitimise particular policy goals and policy tools in relation to the refugee agenda. My findings in this article raise serious questions about the way in which Czech newspaper coverage of refugees reproduced the dominant political discourse, which upheld the country as effectively a no-go zone for refugees (Devereux, 2015). The newspaper coverage of refugee issues amplified the overall negative political attitude towards refugees and helped to justify key policies against refugees during the analysed period. My analysis has shown that although the topic gained coverage from summer 2015 onwards, there was no sudden 'turning point' in Czech policies towards refugees (cf. Triandafyllidou, 2017). Instead, Czechia's unwillingness to accept refugees was deeply embedded in its policies and media discourse from the outset.

It might be difficult for many refugee-receiving countries to understand why countries such as Czechia could not receive as 'few' as approximately 2,600 asylum seekers (e.g. Carrera, 2015). Although I did not primarily seek to answer this question in this article, my analysis captures the main refugee narratives at work during the recent refugee crisis and thus sheds some light on the Czech position. The results of my media analysis, seen from the perspective of the theory of the social construction of target populations, suggest, first, that the negative position towards refugee relocation is deeply embedded in the Czech society and, second, that the Czech antirefugee discourse is very much intertwined with criticism of the European Union. Thus the infringement procedures against Czechia, Hungary and Poland are likely to further deepen the standoff between Brussels and these central European governments.

\section{ACKNOWLEDGEMENTS}

The study was funded by the Czech Science Foundation (GAČR), project No. 16-14292S Does Policy Design Matter? A Comparative Study of Target Populations in the Czech Republic. 


\section{REFERENCES}

Anne Schneider. (2013). Policy design and transfer. In Routledge Handbook of Public Policy (s. 217-228). Routledge.

Braun, V., \& Clarke, V. (2006). Using thematic analysis in psychology. Qualitative Research in Psychology, 3(2), 77-101. https://doi. org/10.1191/1478088706qpo63oa

Carrera, S. (2015, ríjen 2). To adopt refugee quotas or not: Is that the question? Centre for European Policy Studies. Získáno z https://www. ceps.eu/publications/adopt-refugee-quotas-or-not-question

CVVM. (2013). Public Opinion on the Settling of Foreigners in the Czech Republic - March 2013. CVVM (Public Opinion Research Centre). Získáno z https://cvvm.soc.cas.cz/en/press-releases/other/relationsattitudes/4124-public-opinion-on-the-settling-of-foreigners-in-theczech-republic-march-2016

CVVM. (2015). Attitude of Czech Public to Accepting of Refugees - June 2015. CVVM (Public Opinion Research Centre). Získáno z https:// cvvm.soc.cas.cz/media/com_form2content/documents/c2/a1927/fg/ pm150723.pdf

CVVM. (2016). Attitude of Czech Public to Accepting of Refugees December 2016. CVVM (Public Opinion Research Centre). Získáno z https://cvvm.soc.cas.cz/en/press-releases/political/internationalrelations/4222-attitude-of-czech-public-to-accepting-of-refugees-indecember-2016

Czech Statistical Office. (2017). Foreigners in the Czech Republic. Praha.

Devereux, E. (2015). Thinking Outside the Charity Box: Media Coverage of Homelessness. European Journal of Homelessness, 2009(2), 261-273.

Drbohlav, D., \& Valenta, O. (2014). Czechia: the main immigration country in the $\mathrm{V}_{4}$. In Discovering migration between Visegrad countries and Eastern Partners (s. 41-71). Budapest: HAC RCAES Geographical Institute.

Esses, V. M., Hamilton, L. K., \& Gaucher, D. (2017). The Global Refugee Crisis: Empirical Evidence and Policy Implications for Improving Public Attitudes and Facilitating Refugee Resettlement. Social Issues and Policy Review, 11(1), 78-123. https://doi.org/10.1111/sipr.12028

Esses, V. M., Jackson, L. M., \& Armstrong, T. L. (1998). Intergroup Competition and Attitudes Toward Immigrants and Immigration: An Instrumental Model of Group Conflict. Journal of Social Issues, 54(4), 699-724. https://doi.org/10.1111/j.1540-4560.1998.tbo1244.x

Esses, V. M., Medianu, S., \& Lawson, A. S. (2013). Uncertainty, Threat, and the Role of the Media in Promoting the Dehumanization of Immigrants and Refugees. Journal of Social Issues, 69(3), 518-536. https://doi.org/10.1111/josi.12027
Huysmans, J. (2000). The European Union and the Securitization of Migration. JCMS: Journal of Common Market Studies, 38(5), 751-777. https://doi.org/10.1111/1468-5965.00263

Jørgensen, M. B., \& Thomsen, T. L. (2012). Crises Now and ThenComparing Integration Policy Frameworks and Immigrant Target Groups in Denmark in the 1970 s and 200os. Journal of International Migration and Integration. https://doi.org/10.1007/s12134-012-0238-4

King, R., \& Wood, N. (2013). Media and Migration: Constructions of Mobility and Difference. Routledge.

Krzyżanowski, M. (2017). Discursive Shifts in Ethno-Nationalist Politics: On Politicization and Mediatization of the "Refugee Crisis" in Poland. Journal of Immigrant \& Refugee Studies, 1-21. https://doi.org/10.1080/1 5562948.2017 .1317897

Lawlor, A., \& Tolley, E. (2017). Deciding Who's Legitimate: News Media Framing of Immigrants and Refugees. International Journal of Communication, 11(0), 25.

Lovell, T. (2003). Resisting with Authority: Historical Specificity, Agency and the Performative Self. Theory, Culture \& Society, 20(1), 1-17. https:// doi.org/10.1177/0263276403020001918

Murray, K. E., \& Marx, D. M. (2013). Attitudes toward unauthorized immigrants, authorized immigrants, and refugees. Cultural Diversity and Ethnic Minority Psychology, 19(3), 332-341. https://doi.org/10.1037/ a0030812

Perloff, R. M. (2010). The dynamics of persuasion: communication and attitudes in the 21st century (4th ed). New York: Routledge.

Pierce, J. J., Siddiki, S., Jones, M. D., Schumacher, K., Pattison, A., \& Peterson, H. (2014). Social Construction and Policy Design: A Review of Past Applications. Policy Studies Journal, 42(1), 1-29. https://doi. org/10.1111/psj.12040

Public Defender of Rights. (2015). Zařízení pro zajištění cizinců BěláJezová Vyhodnocenísystematické návštěvy (No. Sp. zn.: 24/2015/NZ/OV). Public Defender of Rights in the Czech Republic. Získáno z https://www. ochrance.cz/fileadmin/user_upload/ESO/24-_2015-NZ_Bela-JezovaZZ_vyhodnoceni_rijen_2015_.pdf

Riff, D., Lacy, S., \& Fico, F. (2014). Analyzing Media Messages: Using Quantitative Content Analysis in Research. Routledge.

Rozumek, M. (2017, červenec 27). Haišmanův odchod by měl být novým začátkem (Haisman, director of the Asylum and Migration Department, is leaving, a new start is needed). Deník Referendum. Získáno z http:// denikreferendum.cz/clanek/25741-haismanuv-odchod-by-mel-bytnovym-zacatkem 
Schneider, A., \& Ingram, H. (1993). Social Construction of Target Populations: Implications for Politics and Policy. American Political Science Review, 87(02), 334-347. https://doi.org/10.2307/2939044

Schneider, A., \& Ingram, H. (1997). Policy design for democracy. Lawrence: University Press of Kansas.

Schneider, A., \& Sidney, M. (2009). What Is Next for Policy Design and Social Construction Theory? ${ }^{1}$. Policy Studies Journal, 37(1), 103-119. https://doi.org/10.1111/j.1541-0072.2008.00298.x

Sulaiman-Hill, C. M. R., Thompson, S. C., Afsar, R., \& Hodliffe, T. L. (2011). Changing Images of Refugees: A Comparative Analysis of Australian and New Zealand Print Media 1998-2008. Journal of Immigrant \& Refugee Studies, 9(4), 345-366. https://doi.org/10.1080/15562948.2011.616794

Szczepanikova, A. (2005). Gender Relations in a Refugee Camp: A Case of Chechens Seeking Asylum in the Czech Republic. Journal of Refugee Studies, 18(3), 281-298. https://doi.org/10.1093/refuge/feio32

Szilagyi, A. (2018, únor 2). How Dehumanizing Rhetoric Works. Získáno z https://www.talkdecoded.com/blog/2018/2/2/dangerous-metaphors-1

Tkaczyk, M. (2017). Between Politicization and Securitization: Coverage of the European Migration Crisis in Czech Online News Media. Communication Today; Trnava, 8(2), 90-111.

Triandafyllidou, A. (2017). A "Refugee Crisis" Unfolding: "Real" Events and Their Interpretation in Media and Political Debates. Journal of Immigrant \& Refugee Studies, 1-19. https://doi.org/10.1080/15562948.2 017.1309089

UNHCR. (2015). Zeid urges Czech Republic to stop detention of migrants and refugees. UNHCR. Získáno z http://www.ohchr.org/EN/NewsEvents/ Pages/DisplayNews.aspx?NewsID=16632\&LangID=E

Yoo, G. J. (2008). Immigrants and Welfare: Policy Constructions of Deservingness. Journal of Immigrant \& Refugee Studies, 6(4), 490-507. https://doi.org/10.1080/15362940802479920 